\title{
Pain Management and Life Satisfaction in Elderly Individuals: A Single Centred Study
}

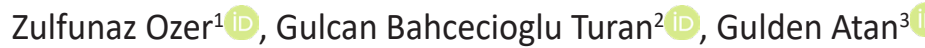 \\ ${ }^{1}$ Department of Nursing, Faculty of Health Sciences, Istanbul Sabahattin Zaim University, Istanbul, Turkey. \\ ${ }^{2}$ Department of Nursing, Faculty of Health Sciences, Firat University, Elazı̆̆, Turkey. \\ ${ }^{3}$ School of Health, Van Yüzüncü Yıl University, Van, Turkey. \\ Correspondence Author: Zulfunaz Ozer \\ E-mail: zulfinazozer@gmail.com
}

Received: $07.05 .2020 \quad$ Accepted: 27.07 .2021

\begin{abstract}
Objective: This study was conducted to find out the pain management status and life satisfaction of elderly individuals living in a nursing home and to determine the relationship between these.

Methods: This descriptive cross-sectional study was conducted in a nursing home in Turkey in November 2019. The data were collected by the researchers with face-to-face interview technique by using "Personal Information Form", "Geriatric Pain Measure (GPM)", "Pain Management Inventory (PMI)" and "Life Satisfaction Scale (LSS)".

Results: GPM total score was $48.95 \pm 11.24$, and average LSS was $14.37 \pm 6.85$. There is a positive statistically significant association between GPM and PMI ( $r=0.385 ; p<0.01)$, while there is a negative statistically significant association between GPM and LSS $(r=-0.369 ; p<0.01)$. There is a negative statistically significant association between PMI and LSS ( $r=-0.344 ; p<0.01)$.

Conclusion: It was found that elderly individuals had moderate level of pain and poor life satisfaction. It was found that as level of pain increased, elderly individuals' life satisfaction decreased.
\end{abstract}

Keywords: Pain, Life Satisfaction, Elderly Nursing Home.

\section{INTRODUCTION}

Aging is the irreversible functional change in the organism with the passing of time. With this change, physical and cognitive functions regress and the individual's potential to balance between systems decrease $(1,2)$. As in the whole world, the elderly population is increasing gradually in Turkey. In Turkey, the rate of 65 years and older population which was $4.3 \%$ in 1990 consensus increased to $8.8 \%$ in 2018. In 2040, it is estimated that the rate of 65 years and older population will reach $16.3 \%$ (3).

Pain is an important health problem (4) which negatively affects the lives of elderly individuals, especially those staying in nursing homes $(5,6)$. Musculoskeletal system problems, neuropathies, cardiovascular diseases and other chronic situations are considered as the most common causes of pain in elderly individuals $(6,7)$. General pain prevalence in the elderly has been reported to be between $50 \%$ and $67 \%$ (8-10). This rate has been reported to differ between $3.7 \%$ and $79.5 \%$ in individuals living in nursing homes (6).

American Pain Association used the expression "pain: fifth sign of life" to emphasize the importance of pain and to increase the awareness of health professionals about pain control (11). Effective pain management is one of the basic human rights and it is among the most important responsibilities of health professionals (12). In pain management, while pharmacologically used drugs have been reported to be effective on somatic pain (emotional and physical), methods such as exercise, cold-hot application, movement restriction, positioning, resting, hydrotherapy, acupuncture, massage and transcutaneous electrical stimulation (TENS) have been found to influence cognitive, emotional, behavioural and socio-cultural dimensions of pain (13). For elderly patients, pain management should improve health and decrease health care expenses. A plan with realistic and correct purposes can provide pain management in elderly individuals (14). In addition, finding our the coping methods that the patient makes use of and increasing their use can provide support to the patient in reliving chronic pain (15). It has been reported that frequent experiences of pain have a negative effect on physical, psychological and social state of well-being (16). 
Life satisfaction is the condition or result that is obtained with the comparison of what the individual wants and has. Life satisfaction expresses the state of well-being in different aspects such as satisfaction, happiness, spirits, etc. in the whole life, not just the satisfaction about a specific condition (17). In elderly individuals, life satisfaction has been associated with the combination of a great number of factors such as personal characteristics, physical possibilities and coping methods (1).

Pain is a personal experience and for this reason, it has a personal effect on life satisfaction (16). It is known that insufficient or untreated pain causes the deterioration of mobility and other functions, sleep disorders, anxiety, depression and in general low quality of life (18). Since functional decrease causes increased care dependence, it has been stated that sufficient pain management is especially important in this sensitive population (19). Due to the multidimensional nature of pain, the way of pain management should be addressed in elderly individuals (20). For the development of elderly health, psychological determinants of health such as life satisfaction should be evaluated. In parallel with this evaluation, it is reported that nurses should plan interventions appropriate to increase suitable pain management and to integrate these to the care plan (21, 22). In a meta analysis conducted, it has been stated that the health professionals working in a nursing home frequently consider pain and suffering as a normal part of life (23). This common belief causes limited pain reports on the one hand and undiagnosed conditions by health professionals on the other hand. In nursing homes, it is important to research and understand all the information about the pain and treatment of all elderly individuals to improve pain management (19). In addition, the methods most commonly used in the pain management of elderly individuals should be determined (22). Based on all these, the present study was conducted to find out the pain management states and life satisfaction of elderly individuals living in a nursing home and to find out the associations between pain management and life satisfaction.

\section{METHODS}

\section{Place and Characteristics of the Study}

This cross sectional descriptive study was conducted to find out the pain management states and life satisfaction of elderly individuals living in a nursing home and to find out the associations between pain management and life satisfaction.

\section{Population and Sample of the Study}

The population of the study consisted of all elderly individuals ( $n: 300)$ staying in a nursing home in November 2019. The sample of the study consisted of 160 patients aged 65 and older who did not have any mental problems that could prevent participation, who had the cognitive competence to answer the questions and who volunteered to participate in the study. Data were collected between 1-30 November 2019.

\section{Data Collection Tools}

The data were collected by the researchers with face-to-face interview technique by using "Personal Information Form", "Geriatric Pain Scale", "Pain Management Inventory" and "Life Satisfaction Scale".

Personal Information Form: This form includes questions about demographic characteristics of the patients such as gender, age, marital status and level of education and questions including the features of the nursing home and pain.

\section{Geriatric Pain Measure}

Geriatric Pain Measure (GPM) is a 24-item multi-dimensional scale developed by Ferrell et al. in 2000 . Its Turkish validity and reliability was conducted by Dursun and Bektaş in 2017. The scale consists of 5 dimensions as disengagement (6, $17,18,19,20,21,24)$, pain intensity $(1,2,3,4,5,22,23)$, pain with ambulation $(9,10,11,12)$, pain with strenuous activities $(8,13,14)$ and pain with other activities $(7,15,16$, $17,22)$. Two of the items in the measure $(17,22)$ are in two of the sub-dimensions together and there are 3 open-ended questions about pain in the scale. 22 of the items in the scale are scored in pairs and the other 2 items are scored according to $0-10$ scale. Total score is found by adding the answers "Yes" and it is between 0 and 42. Each item in the scale is multiplied by 2.38 and converted into $0-100$ system. The final score of the scale is calculated by converting into 0-100 scale. In the assessment of GPM, scores differ between 0 and 100 and a score lower than 0-30 is evaluated as mild pain, a score between 30 and 69 is evaluated as moderate pain and a score of 70 and higher is evaluated as intense pain. GPM Cronbach alpha value was found as 0.85 (24). In our study, Cronbach alpha value was found as 0.89 .

\section{Pain Management Inventory}

Pain Management Inventory (PMI) was developed to examine pain management methods and the effects of these methods. PMI is a 22-item, Likert-type (0-6) scale. If the individual filling in the inventory is not using a method, he will tick the appropriate option and if he used any method in the last week, he will tick the appropriate option and also tick the option/number that best defines how useful the method was in pain management. There are three different results of the scale: (a) the list of the last methods used, (b) the total number of the methods used, (c) usefulness of each method. PMI Cronbach alpha value was found as 0.76 (25). In our study, Cronbach alpha value was found as 0.78 .

\section{Life Satisfaction Scale (LSS)}

It is a 5-item 7-Likert type scale developed to measure life satisfaction (26). Turkish validity and reliability study of the 
scale was conducted by Yetim (2003) (27). The score taken from each item in the scale differs between 1 and 7 , while the total score differs between 5 and 35 . Higher score taken from the scale shows higher life satisfaction. Cronbach alpha value of the scale was found as 0.86 (27). In our study, Cronbach alpha value was found as 0.81 .

\section{Evaluation of the Data}

In the study, descriptive statistics of the variables were given as number, percentage, arithmetic mean and standard deviation. Spearman's correlation coefficient was used in the assessment of the data obtained. Statistical analyses were conducted with SPSS 25 program and significance level was taken as 0.05 ( $p$-value).

\section{Ethical principles of the study}

Approval was taken from the Ethical Board of the Health Sciences Faculty of the Sabahattin Zaim University the study was conducted in (2019/11 numbered) and written permission was taken from the institution the study was conducted in. In addition, written and oral consent was taken from the individuals who participated in the study after the purpose was explained. Permission was taken from the authors who conducted the Turkish validity and reliability study of the scales.

\section{RESULTS}

Average age of the participants was $68.79 \pm 12.26,51,9 \%$ were women, $\mathbf{7 8 . 1 \%}$ were single, $22.5 \%$ were illiterate and $20.7 \%$ were retired. It was found that $68.8 \%$ of the participants had social security, $46.2 \%$ had children, $61.9 \%$ of the elderly individuals had someone to help them with their care, while 29.6\% were independent in their daily life activities and 65\% were satisfied with the nursing home (Table 1).

It was found that $73.1 \%$ of the participants had pain during the day, $47.5 \%$ expressed the type of their pain as tingling, $17.4 \%$ had back pain, $7.4 \%$ had hand and elbow pain, $13.8 \%$ regular exercise and $15 \%$ defined their health status as good. While $8.7 \%$ of the participants needed support about eating and drinking, $11.1 \%$ needed assistance for going to toilet and 12.4\% needed assistance for walking (Table 2).

Table 3 shows the distribution of pain management frequencies and pain management effectiveness scores. While $32.9 \%$ of the participants preferred to rest frequently to manage pain; $28.1 \%$ preferred to take the pain killer prescribed by the physician and $23.1 \%$ preferred to avoid physical activity that would increase pain. However, it was found that the participants did not prefer relaxing methods such as meditation or daydreaming with a guide and TENS (Table 3). The highest pain management effectiveness score averages of the participants are taking the pain killer prescribed by the physician, resting and focusing on the support from personal religious belief. The lowest score averages are using relaxation methods such as meditation and daydreaming (Table 3).
The results of the study showed that GPM total score average was $48.95 \pm 11.24 ; 27.7 \%(n=44)$ of the elderly individuals felt mild pain, while $47.1 \%(n=75)$ felt moderate pain and $25.2 \%(n=41)$ felt intense pain. Average LSS was found as $14.37 \pm 6.85$.

There is a positive and weak statistically significant association between GPM and PMI ( $r=0.385 ; p<0.01)$ (Table 4). There is a negative and weak statistically significant association between GPM and LSS ( $r=-0.369 ; p<0.01)$ (Table 4). There is a negative and weak statistically significant association between PMI and LSS ( $r=-0.344 ; p<0.01)$ (Table 4).

Table 1. Socio-demographic characteristics of the participants (n:160)

\begin{tabular}{|c|c|c|c|}
\hline & & Ave $\pm S d$ & $\begin{array}{l}\text { Min-Max } \\
\text { (Median) }\end{array}$ \\
\hline \multicolumn{2}{|l|}{ Age } & $68.79 \pm 12.26$ & $\begin{array}{c}24-99 \\
(69.00)\end{array}$ \\
\hline \multicolumn{2}{|c|}{ Number of children } & $1.28 \pm 1.59$ & $0-6(0.00)$ \\
\hline \multicolumn{2}{|c|}{ Total time in the nursing home } & $7.41 \pm 7.84$ & $1-42(5.00)$ \\
\hline \multirow{2}{*}{\multicolumn{2}{|c|}{ Number of people staying in the room }} & $4.62 \pm 1.19$ & $1-7(4.00)$ \\
\hline & & $\mathrm{n}$ & $\%$ \\
\hline \multirow[t]{2}{*}{ Gender } & Female & 83 & 51.9 \\
\hline & Male & 77 & 48.1 \\
\hline \multirow[t]{2}{*}{ Marital Status } & Married & 35 & 21.9 \\
\hline & Single & 125 & 78.1 \\
\hline \multirow[t]{6}{*}{ Level of education } & Illiterate & 36 & 22.5 \\
\hline & Literate & 24 & 15.0 \\
\hline & Primary & 50 & 31.3 \\
\hline & Secondary & 26 & 16.3 \\
\hline & High school & 20 & 12.5 \\
\hline & $\begin{array}{l}\text { Undergraduate and } \\
\text { higher }\end{array}$ & d & 2.5 \\
\hline \multirow[t]{4}{*}{ Profession } & Retired & 33 & 20.7 \\
\hline & Worker & 22 & 13.8 \\
\hline & Self-employed & 37 & 23.3 \\
\hline & Housewife & 67 & 42.1 \\
\hline \multirow{2}{*}{$\begin{array}{l}\text { Presence of Social } \\
\text { Security }\end{array}$} & Yes & 110 & 68.8 \\
\hline & No & 50 & 31.2 \\
\hline \multirow[t]{2}{*}{ Presence of Children } & No & 86 & 53.8 \\
\hline & Yes & 74 & 46.2 \\
\hline \multirow{2}{*}{$\begin{array}{l}\text { Presence of assistant } \\
\text { in care }\end{array}$} & No & 61 & 38.1 \\
\hline & Yes & 99 & 61.9 \\
\hline \multirow[t]{2}{*}{ State of smoking } & No & 100 & 62.5 \\
\hline & Yes & 60 & 37.5 \\
\hline \multirow[t]{3}{*}{ Daily life activities } & Independent & 46 & 29.6 \\
\hline & Semi-dependent & 85 & 53.1 \\
\hline & Fully dependent & 29 & 18.1 \\
\hline \multirow{2}{*}{$\begin{array}{l}\text { State of being satisfied } \\
\text { with the nursing home }\end{array}$} & No & 56 & 35 \\
\hline & Yes & 104 & 65 \\
\hline
\end{tabular}


Table 2. Some of the health habits of participants

\begin{tabular}{|c|c|c|c|}
\hline & & $n$ & $\%$ \\
\hline \multirow[t]{2}{*}{ Pain during the day } & No & 43 & 26.9 \\
\hline & Yes & 117 & 73.1 \\
\hline \multirow[t]{5}{*}{ Type of pain* } & Tingling & 57 & 47.5 \\
\hline & Strenuous & 19 & 15.9 \\
\hline & Sensitive & 10 & 8.3 \\
\hline & Throbbing & 24 & 20.0 \\
\hline & Contracting & 10 & 8.3 \\
\hline \multirow[t]{8}{*}{ Area of pain* } & Head & 47 & 13.9 \\
\hline & Neck-Shoulder & 38 & 11.2 \\
\hline & Waist & 54 & 15.9 \\
\hline & Back & 59 & 17.4 \\
\hline & Hip & 37 & 10.9 \\
\hline & Hand and elbow & 25 & 7.4 \\
\hline & Knee & 43 & 12.7 \\
\hline & Ankle & 36 & 10.6 \\
\hline \multirow{2}{*}{$\begin{array}{l}\text { State of doing regular } \\
\text { exercise }\end{array}$} & Yes & 138 & 13.8 \\
\hline & No & 22 & 86.2 \\
\hline \multirow[t]{3}{*}{ Health Status } & Good & 24 & 15 \\
\hline & Moderate & 106 & 66.2 \\
\hline & Bad & 30 & 18.8 \\
\hline \multirow{8}{*}{$\begin{array}{l}\text { Issues that need } \\
\text { assistance* }\end{array}$} & Eating-drinking & 56 & 8.7 \\
\hline & Shopping & 90 & 14.0 \\
\hline & Going to hospital & 110 & 17.0 \\
\hline & $\begin{array}{l}\text { Buying drug from } \\
\text { pharmacy }\end{array}$ & 110 & 17.0 \\
\hline & Going to toilet & 72 & 11.1 \\
\hline & Having bath & 88 & 13.6 \\
\hline & Walking & 80 & 12.4 \\
\hline & $\begin{array}{l}\text { Speaking on the } \\
\text { phone }\end{array}$ & 40 & 6.2 \\
\hline
\end{tabular}

*More than one option ticked.

Table 4. Correlation analysis between $L S S^{*}, G P M^{* *}$ and $P M I^{* * *}$

\begin{tabular}{llll} 
& & LSS & GPM \\
\hline \multirow{2}{*}{ LSS } & $r$ & 1 & -0.369 \\
\cline { 2 - 4 } & $p$ & - & $\mathbf{0 . 0 0 1} \mathbf{1}^{* * * *}$ \\
\hline GPM & $r$ & -0.369 & 1 \\
& $p$ & $\mathbf{0 . 0 0 1 * * * *}$ & - \\
\hline PMI & $r$ & -0.344 & 0.385 \\
& $p$ & $\mathbf{0 . 0 0 1 * * * *}$ & $\mathbf{0 . 0 0 1 * * * *}$ \\
\hline
\end{tabular}

*LSS: Life Satisfaction Scale, ${ }^{*}$ GPM: Geriatric Pain Measure, PMI: Pain Management Inventory, Spearman's Korelasyon ${ }^{* * *} p<0,01$
Table 3. Distribution of the frequency of pain management and pain management effectiveness scores.

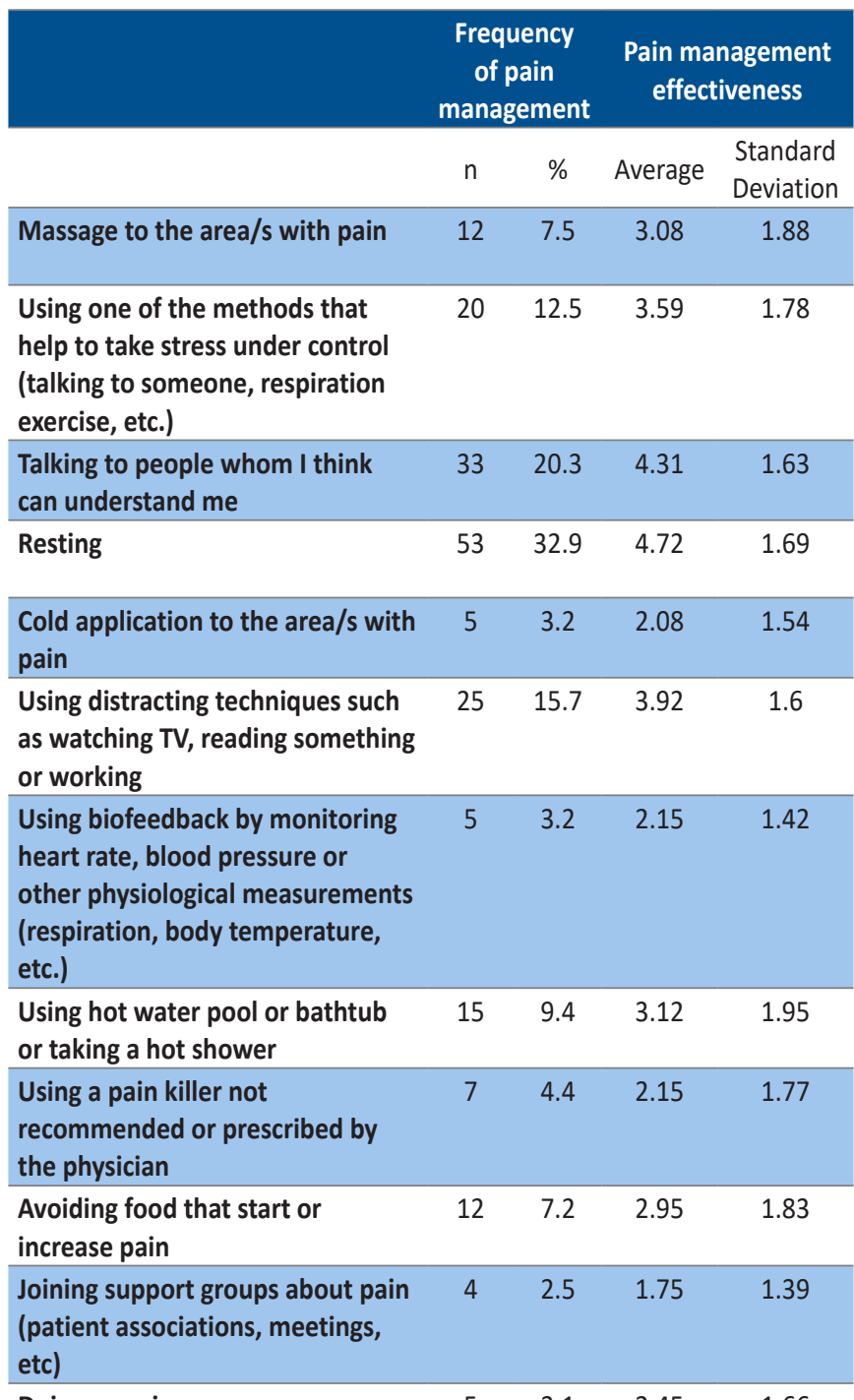

\begin{tabular}{lllll}
\hline Doing exercise & 5 & 3.1 & 2.45 & 1.66
\end{tabular}

\begin{tabular}{lllll|}
\hline $\begin{array}{l}\text { Hot application to the area/s with } \\
\text { pain }\end{array}$ & 4 & 2.5 & 2.31 & 1.54 \\
\hline $\begin{array}{l}\text { Taking antidepressant prescribed } \\
\text { by the physician }\end{array}$ & 9 & 5.3 & 2.83 & 1.84 \\
\hline $\begin{array}{l}\text { Using relaxation methods such as } \\
\text { meditation or daydreaming with } \\
\text { a guide }\end{array}$ & - & - & - & - \\
$\begin{array}{l}\text { Using transcutaneous electrical } \\
\text { stimulation (TENS) }\end{array}$ & - & - & - & - \\
\hline $\begin{array}{l}\text { Supporting the area/s in pain by } \\
\text { using splint or band }\end{array}$ & 3 & 1.5 & 1.86 & 1.48 \\
\hline $\begin{array}{l}\text { Taking pain killer prescribed by the } \\
\text { physician }\end{array}$ & 45 & 28.1 & 4.83 & 1.45 \\
\hline $\begin{array}{l}\text { Avoiding physical pain that will } \\
\text { increase pain }\end{array}$ & 37 & 23.1 & 423 & 1.75 \\
\hline $\begin{array}{l}\text { Using positive suggestions such as } \\
\text { "I can ........ }\end{array}$ & 6 & 3.8 & 2.73 & 1.65 \\
\hline $\begin{array}{l}\text { Planning resting periods between } \\
\text { activities }\end{array}$ & 27 & 16.9 & 4.26 & 1.58 \\
\hline $\begin{array}{l}\text { Focusing on the support from } \\
\text { personal religious belief }\end{array}$ & 34 & 21.3 & 4.4 & 1.46 \\
\hline
\end{tabular}




\section{DISCUSSION}

This study was conducted to find out the pain, pain management and life satisfaction levels of elderly individuals living in nursing homes and the association between these. In the study, it was found that the highest rates of pain were in the areas of back, waist, head, knee, hips, ankle and hand with knee. In different studies conducted, it was found that pain in elderly individuals were similar to the results of this study $(16,22,28,29)$.

In the study, $47.5 \%$ of the elderly individuals experienced tingling pain, while $20 \%$ experienced throbbing pain and 15.9\% experienced strenuous pain. In their study, Yıldız et al. (2009) found that $36.4 \%$ of the elderly individuals experienced tingling pain, while $3.6 \%$ experienced blunt pain. In Özel et al.'s study (2014), it was found that $59.8 \%$ of the elderly patients experienced tingling pain, while $50 \%$ experienced strenuous pain, $75.6 \%$ experienced sensitive pain and $11 \%$ experienced contracting pain. Our study showed similar results with the studies conducted.

In the present study, it was found that in pain management, elderly individuals preferred mostly resting, taking pain killers prescribed by the physician, avoiding physical activity that can increase pain, focusing on the support from personal religious belief and talking to someone that could understand them. Different studies conducted have shown that pain management methods of elderly individuals were similar to those in our study $(22,30-31)$.

In the study, it was found that the methods used with the lowest rates were supporting the area/s in pain by using splint or band, joining support groups about pain, hot and cold application to the area with pain and biofeedback. In addition, it was found that elderly individuals did not use the methods of relaxation such as meditation or daydreaming with a guide in the management of pain. Similar results were found in Özel et al.'s (2014) study. It is thought that elderly individuals do not use these methods since they do not know about these methods exactly and they do not know how to do these methods.

Average GPM total scores of the elderly individuals was $48.95 \pm 11.24$ and it can be said that they had moderate level of pain. In a study they conducted on elderly women, Kapucu and Ünver (2017) found that average GPM total score was $57.6 \pm 17.5$ (32). In their study they conducted on elderly individuals who referred to Family Health Centre, Arli et al. (2018) reported average GPM total score as $53.23 \pm 29.40$. In their study they conducted on 1059 elderly individuals in Europe and United States of America, Blozik et. al. (2007) found average GPM total score as $36.0 \pm 21.7$ in Europe (as $36.0 \pm 21.90$ in England (London), as 39.3 \pm 22.00 in Germany (Hamburg), as $32.7 \pm 21.3$ in Sweden (Solothurn)) and as $42.5 \pm 25.4$ in United States of America. Gökkaya et al. (2012) and Motta et al. (2015) found average GPM total score as $60.4 \pm 22.1$ and $53.0 \pm 17.9$, respectively. The data found in the present study supports the literature data that elderly individuals in the society experience moderate level of pain.
In this study, it was found that according to GPM average scores, $27.7 \%$ of the elderly individuals experienced mild pain, while $47.1 \%$ experienced moderate pain and $25.2 \%$ experienced intense pain. In their study they conducted on elderly women, Kapucu and Ünver (2017) found that 6.7\% experienced mild pain, while $67.3 \%$ experienced moderate pain and $26 \%$ experienced intense pain. According to a study conducted by Dursun and Bektaş (2016), it was found that $48.8 \%$ of the elderly individuals experienced mild pain, while $43 \%$ experienced moderate pain and $8.2 \%$ experienced intense pain. In a study by Gökkaya et al. (2012), it was found that $50.9 \%$ experienced moderate pain and $37.6 \%$ experienced intense pain (35). In their study, Park et. al. (2009) found that $33 \%$ of elderly individuals experienced mild pain, while $56 \%$ experienced moderate pain and $11 \%$ experienced intense pain (37). When these results are examined, it can be thought that the differences in the rates of experiencing pain found in literature can be due to the different features such as the age, gender and life conditions of the elderly individuals in each sample.

In this study, it was found that average LSS total score of elderly individuals was $14.37 \pm 6.85$. As a result of this study, it can be said that elderly individuals have poor life satisfaction levels. In their study they conducted on elderly individuals living in nursing homes, Altay and Avc (2009) and Altıparmak (2009) found average LSS scores as $20.3 \pm 5.9$ and 23.1 \pm 6.3 , respectively. In their study conducted on elderly individuals Kiarsipour et al. (2017) found average LSS scores as $22.39 \pm 6.19$ (39). Average LSS scores in our study were found to be lower than those of the studies conducted in literature. When these results are examined, it can be thought that the differences in the rates of experiencing life satisfaction found in literature can be due to the different features such as life conditions of the elderly individuals in each sample.

In the present study, a positive significant association was found between GPM and PMI. In literature, it is stated that with the increase in the frequency of using pain management methods, the intensity of pain decreases $(40,41)$. In line with this result, it can be said that pain decreases as pain management increases in elderly individuals. In the study, a negative significant association was found between LSS, GPM and PMI. Arli et al. (2018) found a negative association between elderly individuals' pain and their life satisfaction. In literature, pain is a subjective experience that can occur in very different quality and intensities and it is stated that it has a negative effect on the life quality, physical functions and well-being of elderly individuals (16). It is stated that increase in pain causes depression, social isolation, sleep problems, deteriorated activity and economic loss with the use of health services in elderly individuals. As a result of this, quality of life and life satisfaction decreases in elderly individuals (10, $22,42-44)$. The results of the studies conducted support our results. In parallel with this result, it can be said that as life satisfaction decreases in elderly individuals, pain and pain management methods which are used to decrease pain increase. 


\section{CONCLUSION}

The present study gives significant information about pain, pain management and life satisfaction in elderly individuals. In the study, it was found that elderly individuals experienced back, waist, head and knee pain the most. It was found that elderly individuals experienced tingling, throbbing and strenuous pain and in pain management they preferred the methods of resting, taking pain killer prescribed by the physician and avoiding physical activity that can increase pain. It was found that elderly individuals experienced moderate level of pain and they had poor life satisfaction levels. A negative statistically significant association was found between LSS, GPM and PMI. Pain decreases life satisfaction in elderly individuals. For this reason, individuals' pain must be well-defined and treated.

In line with these results, it can be recommended to include individuals working in the nursing homes in the methods used by elderly individuals in pain management and the personnel working in nursing homes and patients should be trained about how to use these. In addition, it is recommended to conduct studies to find out when it is the best to use pharmacological or non-pharmacological interventions and to learn how to find the best intervention and to know the pain beliefs of all stakeholders clearly.

\section{Limitations}

Since the present study is limited to the elderly individuals living in a nursing home, it cannot be generalized to the whole population.

\section{Acknowledgements}

The authors desire to thank all the participants in the study.

\section{REFERENCES}

[1] Özer M, Karabulut Ö. Yaşlılarda yaşam doyumu (Satisfaction of life in elderly individuals). Geriatri 2003; 6(2): 72-74. (Turkish)

[2] Top FÜ, Saraç A, Yaşar G. Huzurevinde yaşayan bireylerde depresyon düzeyi, ölüm kaygısı ve günlük yaşam işlevlerinin belirlenmesi (Depression, death anxiety and daily life functioning in the elderly living in nursing home). Klinik Psikiyatri 2010; 13: 14-22. (Turkish)

[3] TÜiK. İstatistiklerle yaşlılar 2018. Available from: http://www. tuik.gov.tr/PreHaberBultenleri.do?id=30567 (accessed 22 November 2019)

[4] Miró J, Paredes S, Rull M, Queral R, Miralles R, Nieto R, Huguet A, Baos J. Pain in older adults: A prevalence study in the mediterranean region of catalonia. European Journal of Pain 2007; 11(1): 83-92.

[5] Schreier M, Stering U, Pitzer S, Iglseder B, Osterbrink J. Pain and pain-assessment in nursing homes: Results of the OSiA study. Schmerz (Berlin, Germany) 2015; 29(2): 203-210.

[6] Takai Y, Yamamoto-Mitani N, Okamoto Y, Koyama K, Honda A. Literature review of pain prevalence among older residents of nursing homes. Pain Management Nursing 2010; 11(4): 209223.

[7] Leveille SG, Zhang Y, McMullen W, Kelly-Hayes M, Felson DT. Sex differences in musculoskeletal pain in older adults. Pain 2005; 116(3): 332-338.

[8] Güler G, Güler N, Kocataş S, Akgül N. Yaşılıarın sağlık bakım gereksinimleri (Health care needs of elderly). Cumhuriyet Medical Journal 2009; 31(4): 367-373. (Turkish)

[9] Olgun N, Aslan FE, Yücel N, Öntürk ZK, Laçin Z. Yaşılıarın sağlık durumlarının değerlendirilmesi (Assessment of health status of the elderly). Acıbadem Üniversitesi Sağlık Bilimleri Dergisi 2013; 4(2): 72-78. (Turkish)

[10] Yıldız A, Erol S, Ergün A. Bir huzurevinde kalan yaşlılarda ağrı ve depresyon riski (Pain and depression risk among elderly people living in a nursing home). Turkish Journal of Geriatrics 2009; 12(3): 156-162. (Turkish)

[11] Davtalab E, Naji S, Shahidi S. Comparing the effects of Valsalva maneuver and ice massage at Hoku point methods on pain intensity within the needle insertion to the arteriovenous fistula (AVF) for patients undergoing hemodialysis in the selected hospitals in Isfahan in 2015. International Journal of Medical Research \& Health Sciences 2016; 5(5): 101-107.

[12] Özyiğit S, Yıldırım Y, Karaman E. Pain in hemodialysis patients. Turk Neph Dial Transpl 2016; 25(1): 88.

[13] Akça NK, Arslan D. Pain and coping methods of individuals under 65 years of age on hemodialysis treatment. Türk Nefroloji, Diyaliz ve Transplantasyon Dergisi 2015; 24(3): 278282.

[14] Davis GC, White TL. A goal attainment pain management program for older adults with arthritis. Pain Management Nursing 2008; 9(4): 171-179.

[15] Özkan ZK, Ünver S, Başar A. Karpal tünel sendromlu hastalarda ağrı kontrolünde kullanılan yöntemlerin değerlendirilmesi. Ağrı 2016; 28(4): 177-182. (Turkish)

[16] Tavşanlı NG, Özçelik H, Karadakovan A. Ağrısı olan yaşlı bireylerin yaşam kalitesinin incelenmesi. Ağrı 2013; 25(3): 93100. (Turkish)

[17] Altay B, Avcı IA. Huzurevinde yasayan yaslılarda özbakım gücü ve yasam doyumu arasındaki ilişki. Dicle Tıp Dergisi 2009; 36(4): 275-282. (Turkish)

[18] Smith TO, Purdy R, Latham SK, Kingsbury SR, Mulley G, Conaghan PG. (2016). The prevalence, impact and management of musculoskeletal disorders in older people living in care homes: a systematic review. Rheumatology International 2016; 36(1): 55e64.

[19] Brunkert T, Simon M, Haslbeck J, Zúñiga F. Who to Talk to About my pain? A brief qualitative study on perception of pain and its management in swiss nursing home residents. Pain Management Nursing 2020; 21(2): 151-156.

[20] Damsgård E, Solgård H, Johannessen K, Wennevold K, Kvarstein G, Pettersen G, Garcia B. Understanding pain and pain management in elderly nursing home patients applying an interprofessional learning activity in health care students: A Norwegian pilot study. Pain Management Nursing 2018; 19(5): 516-524.

[21] Erol S, Sezer A, Şişman FN, Öztürk S. Yaşlılarda Yalnızlık algıSı ve yaşam doyumu. Gümüşhane Üniversitesi Sağlık Bilimleri Dergisi 2016; 5(3): 60-90. (Turkish)

[22] Özel F, Yıldııım Y, Fadıloğlu Ç. Huzurevinde yaşayan yaşılıarda ağrı yönetimi. Ağrı 2014; 26(2): 57-64. (Turkish) 
[23] Vaismoradi M, Skär L, Söderberg S, Bondas TE. Normalizing suffering: A meta-synthesis of experiences of and perspectives on pain and pain management in nursing homes. International Journal of Qualitative Studies on Health and Well-being 2016; 11(1): 31203.

[24] Dursun G, Bektas H. Cultural validation and reliability of the Turkish version of the geriatric pain measure in the elderly. Pain Practice 2017; 17(4): 505-513.

[25] Davis GC, Atwood JR. The development of the Pain Management Inventory for patients with arthritis. J Adv Nurs 1996; 24(2): 236-243.

[26] Diener E, Emmons RA, Larsen RJ, Griffin S. The satisfaction with life scale. Journal of Personality Assessment 1985; 49(1): 71-75.

[27] Yetim U. The impacts of individualism/collectivism, selfesteem, and feeling of mastery on life satisfaction among the Turkish university students and academicians. Social Indicators Research 2003; 61(3): 297-317.

[28] Tse M, Wan VT, Wong AM. Pain and pain-related situations surrounding community-dwelling older persons. Journal of Clinical Nursing 2013; 22(13-14): 1870-1879.

[29] Karadağ E, Sevinç S. Tunceli'de Yaşayan yaşlı bireylerin ağrılı durumlarda başvurdukları geleneksel uygulamalar. Spatula DD 2014; 4(4): 179-186. (Turkish)

[30] Yu H-Y, Tang F-I, Yeh M-C, Kuo BI-T, Yu S. Use, perceived effectiveness, and gender differences of pain relief strategies among the community-dwelling elderly in Taiwan. Pain Management Nursing 2011; 12(1): 41-49.

[31] Zanocchi M, Maero B, Nicola E, Martinelli E, Luppino A, Gonella M, Gariglio F, Fissore L, Bardelli B, Obialero R. Chronic pain in a sample of nursing home residents: prevalence, characteristics, influence on quality of life (QoL). Archives of Gerontology and Geriatrics 2008; 47(1): 121-128.

[32] Kapucu S, Ünver G. Pain and frailty in elderly females with osteoporosis. Turkish Journal of Geriatrics 2017; 20(4): 306314.

[33] Arli SK, Bakan AB, Varol E, Aslan G. Investigation of pain and life satisfaction in older adults. Geriatrics \& Gerontology International 2018; 18(1): 5-11.

[34] Blozik E, Stuck AE, Niemann S, Ferrell BA, Harari D, RentelnKruse Wv, Gillmann G, Beck JC, Clough-Gorr KM. Geriatric pain measure short form: development and initial evaluation. Journal of the American Geriatrics Society 2007; 55(12): 20452050
[35] Gökkaya NKO, Gokce-Kutsal Y, Borman P, Ceceli E, Dogan A, Eyigor S, Karapolat H. Pain and quality of life (QoL) in elderly: The Turkish experience. Archives of Gerontology and Geriatrics 2012; 55(2): 357-362.

[36] Motta TSd, Gambaro RC, Santos FC. Pain measurement in the elderly: evaluation of psychometric properties of the Geriatric Pain Measure-Portuguese version. Revista Dor 2015; 16(2): 136-141.

[37] Park J, Cho B, Paek Y, Kwon H, Yoo S. Development of a pain assessment tool for the older adults in Korea: the validity and reliability of a Korean version of the geriatric pain measure (GPM-K). Archives of Gerontology and Geriatrics 2009; 49(2): 199-203.

[38] Altıparmak S. Huzurevinde yaşayan yaşlı bireylerin yaşam doyumu, sosyal destek düzeyleri ve etkileyen faktörler. Fırat Üniversitesi Sağlık Bilimleri Tıp Dergisi 2009; 23(3): 159-164. (Turkish)

[39] Kiarsipour N, Borhani F, Esmaeili R, Zayeri F. The correlation of aging perceptions and life satisfaction in Iranian older adults. Annals of Tropical Medicine and Public Health 2017; 10(4): 861.

[40] Ganji R, Pakniat A, Armat MR, Tabatabaeichehr M, Mortazavi $H$. The effect of self-management educational program on pain intensity in elderly patients with knee osteoarthritis: a randomized clinical trial. Macedonian Journal of Medical Sciences 2018; 6(6): 1062.

[41] Parlar S, Fadiloglu C, Argon G, Tokem Y, Keser G. The Effects of Self-Pain management on the intensity of pain and pain management methods in arthritic patients. Pain Management Nursing 2013; 14(3): 133-142.

[42] Kankaya H, Karadokovan A. Yaşlı bireylerde günlük yaşam aktivite düzeylerinin yaşam kalitesi ve yaşam doyumuna etkisi. Gümüşhane Üniversitesi Sağlık Bilimleri Dergisi 2017; 6(4): 2129. (Turkish)

[43] Gümüş AB, Keskin G, Orgun F. Huzurevinde yaşayan yaşıllarda ağrı ve yaşam aktiviteleri: depresyon, anksiyete ve somatizasyon yönünden bir inceleme. Türk Geriatri Dergisi 2012; 15(3). (Turkish)

[44] Paterson DH, Warburton DE. Physical activity and functional limitations in older adults: A systematic review related to Canada's Physical Activity Guidelines. International Journal of Behavioral Nutrition and Physical Activity 2010; 7(1): 38. 